\title{
PROBLEMAS DE FILOSOFIA DO DIREITO
}

\author{
POSNER, Richard A. Problemas de filosofia do direito. São Paulo: Martins Fontes, \\ 2007
}

Caroline Müller Bitencourt ${ }^{1}$

Richard Posner ao descrever em seu prefácio os motivos pelo qual tal obra denominou-se "problemas da filosofia do direito", relatou algumas questões que estão presentes no centro dessa discussão: como a objetividade e a autonomia do direito, em contraponto com sua possível pessoalidade e seu caráter político; o significado de justiça e portanto, o verdadeiro papel de um juiz; o papel da filosofia moral no direito; a questão se vislumbrar o direito como uma ciência bem como a problemática relativa à sua interpretação e aplicação. Problemas esses, que para o autor norte americano não podem ser resolvidos pelos métodos jurídicos tradicionais e convencionais, e nem mesmo podem ser reduzidos a doutrinas e raciocínios jurídicos.

Para tanto, o autor se propõe a utilizar da filosofia analítica, por isso, defende:

\begin{abstract}
(...) uma filosofia do direito que seja crítica ao formalismo e tenha afinidades como o realismo jurídico, desde que despojado da política do centro esquerda que é característica desse movimento e de sua descendência. Refiro-me a uma filosofia do direito que, como o realismo jurídico, faz uso da filosofia do pragmatismo (ainda que não seja apenas desta filosofia) mas que, ao contrário de algumas versões do realismo, procura desmitologizar o direito sem denegri-lo ou santificá-lo. (Posner, 2007, p. XII)
\end{abstract}

Tendo em mente a advertência do autor de que não se trata de um livro sobre filosofia do direito, mas sobre os problemas os quais tal produção remete, o autor não busca discutir ou aprofundar autores ou temas clássicos da filosofia do direito, mas sim problematizá-los no âmbito de uma solução concreta que possa ser útil ao direito. Com esse espírito, e face da tarefa Hérculea que seria resenhar toda a complexa obra do autor no tocante a todos os problemas da filosofia do direito que o

\footnotetext{
${ }^{1}$ Doutora em Direito. Especialista em Direito Público. Professora do PPGD - Mestrado e Doutorado em Direito da Universidade de Santa Cruz do Sul, da disciplina Teoria do Direito. Professora da graduação e pós-graduação lato sensu da Universidade de Santa Cruz do Sul. Subcoordenadora do curso de Direito da Universidade de Santa Cruz do Sul - Campus Sobradinho. Coordenadora do grupo de pesquisa Teorias de Decisão Judicial, vinculado ao CNPq. Advogada. Contato: caroline.mb@terra.com.br.
} 
mesmo aborda, seleciono determinadas temáticas a fim de expor o pensamento de Posner de forma mais clara e fiel possível.

No início de sua obra no capítulo intitulado "o direito como lógica, regras e ciência", encontra-se um dos momentos mais centrais para o deslinde do texto, pois busca refletir como as respostas jurídicas podem ser produzidas, bem como o tipo de raciocínio a ela empregados, na medida que, de imediato anuncia que a indeterminabilidade é fenômeno praticamente inerente ao conceito de direito, sendo que, mesmo diante desse estado, o direito terá de produzir suas respostas.

Posner delimita sua abordagem ao questionar, de forma direta, até onde 0 direito é objetivo, impessoal e preciso. Imediatamente propõe, em suas palavras, uma resposta "moderadamente cética", dividida em duas etapas. Na primeira, explica que muitas questões jurídicas não podem ser respondidas fazendo uso de métodos do raciocínio jurídico, por estes serem pouco potentes como instrumentos de construção. Na segunda etapa, indica que a resposta (ou solução) do conflito é seguidamente indeterminada, pois quando o raciocínio jurídico se esgota, o juiz tem de recorrer a mecanismos pessoais, como seus valores, crenças e à opinião pública. (POSNER, 2007)

Partindo do pressuposto que a indeterminabilidade é o estado no qual quase sempre se encontra o Direito, Posner procura um termo intermediário entre o que seria a "resposta-correta" e a "razão artificial", tendo em vista que nega as duas, fazendo oposição ao ceticismo radical que iguala o direito à política, também discordando da posição que trata todas as questões jurídicas como indeterminadas. A investigação exata, então, torna-se o meio pelo qual o autor pesquisa a maneira como os juízes podem adquirir crenças verdadeiras sobre questões jurídicas. $O$ método em destaque, primeiramente, é o silogismo. (POSNER, 2007)

O silogismo, aparentemente infalível, considera a validade do argumento, e não a verdade da conclusão. Esta dependerá da verdade das premissas. Essa ideia fica clara quando é ilustrada com o exemplo: todos os espartanos são sábios; Sócrates é espartano; portanto, Sócrates é sábio. Nesse caso, coexistem validade e falsidade, indício da fragilidade do raciocínio silogístico.

O formalismo jurídico, criticado por Holmes, é caracterizado pelo uso excessivo do silogismo. Conforme Posner: 
quando usado de modo não pejorativo, o formalismo pode referir-se a uma crença forte - mas talvez justificadamente forte - na possibilidade de se obter respostas certas a questões jurídicas por meio de métodos convencionais de análise jurídica [...] ou o formalismo pode referir-se simplesmente ao uso da lógica para raciocinar a partir de premissas que permitam chegar a conclusões jurídicas.(POsner, 2007, p.53)

O autor ressalva, no entanto, que o sentido mais útil do termo "formalismo jurídico", dito multiforme, vem do contraste entre forma e substância, como aquele presente entre justiça formal e material. Expõe Posner (2007, p.53) que a autonomia e a objetividade do direito "são asseguradas pela delimitação da análise jurídica ao nível formal", onde apenas se explora a relação entre ideias jurídicas. Note-se, nesse caso, que em situações nas quais o resultado jurídico depender de fatos do mundo, a autonomia e a objetividade citadas serão ameaçadas.

O formalismo pode aparecer tanto no direito natural quanto no direito positivo. Constatadamente, o pré-requisito para ser um formalista é "ter uma suprema confiança nas próprias premissas e nos próprios métodos de extrair conclusões delas." Por isso, existem tantos formalistas jusnaturalistas quanto positivistas. Este último, por exemplo, "está convencido de que o direito consiste apenas nas ordens legislativas, ou em outros comandos oficiais que, cuidadosamente interpretados, produzem resultados demonstravelmente corretos em todos os casos." (Posner, 2007, p.54).

Para o formalismo, que tende a ser contrário às transformações jurídicas,

a premissa mais segura para deduzir o resultado de um novo caso é a decisão do caso mais recente que apresentou, essencialmente, os mesmos fatos, de modo que a norma expressa por esse caso, ou nele implícita, se ajusta como uma luva ao novo caso. (Posner, 2007, p.54)

O silogismo, embora enfatizado, não é, naturalmente, a única forma elementar de lógica empregada pelos operadores do direito. É utilizado, por exemplo, o princípio de que uma proposição não pode ser ao mesmo tempo verdadeira e falsa, ou que, se duas coisas forem idênticas a uma terceira, serão idênticas entre si. A linguagem lógica é aplicada até mesmo em situações em que não o seria cabível. Ainda assim, segundo Posner (2007, p.55), "é igualmente enganoso sugerir que a lógica informa, de modo útil, a idéia (sic) de dar o mesmo tratamento a coisas semelhantes", pois sem a especificação do que seria o critério de semelhança, a proposição lógica de que coisas são idênticas para si próprias, e 
de que duas coisas idênticas a uma terceira são idênticas entre si, torna a ideia vazia para o direito. Nesse sentido, esclarece que

\begin{abstract}
o princípio jurídico do igual tratamento distingue as diferenças entre os litigantes que podem ser adequadamente consideradas na alocação dos benefício e encargos legais, como as diferenças em termos de habilidade e empenho, daquelas que, às vezes ou sempre, podem não sê-lo, como as diferenças de religião, raça, classe social, renda ou relação com o juiz. (Posner, 2007, p.56)
\end{abstract}

Os juízes, para resolver questões jurídicas, muito buscam extrair, seja de leis e/ou de decisões anteriores, regras com as quais irão estabelecer premissas para decidir os casos silogisticamente. Muitas dessas questões jurídicas, no entendimento de Posner, (2007, p. 57) "não são apenas determinadas no sentido aproximado de determinação lógica; trata-se, exatamente, daquelas que adquirem maior importância para as pessoas comuns quando elas pensam sobre o direito." $\mathrm{O}$ autor ainda complementa:

\begin{abstract}
estas, e muitas outras questões jurídicas, são respondidas dedutivamente mediante a aplicação de regras claras e pacíficas a fatos concretos ou admitidos por hipótese. O motivo de tais questões não aparecerem muito no debate jurídico e, na verdade, permanecerem quase além do horizonte profissional está no fato de serem demasiado simples para se tornarem objeto de litígios, ou mesmo de exigirem assistência jurídica. Ao se filosofar sobre o direito, isso faz com que seja fácil - fácil demais - esquecer essas questões e pressupor que todas as questões jurídicas são indeterminadas. (Posner, 2007, p.58)
\end{abstract}

Nesse ponto, vale reiterar a importante distinção entre a validade de um silogismo e sua solidez. A capacidade de levar a uma conclusão verdadeira do silogismo dependerá não apenas da validade do mesmo, mas também da verdade das premissas por ele formado. Com as regras jurídicas, esta será uma tarefa quase sempre difícil, dependendo da generalidade da regra, preconiza Posner. Estabelecer a premissa menor (no caso jurídico, decidir as questões de fato) encontra a dificuldade de que a definição legal destes não é, exclusivamente, um processo lógico. Neste caso, fala-se que uma regra que exija uma investigação factual relativamente ampla para o estabelecimento da premissa menor será frequentemente denominada "padrão", contrastando com aquela onde a premissa menor afirma um fato único. Isso, entretanto, não implica dizer que o tipo mais 
simples de regra será sempre mais fácil de ser aplicado. Ainda assim, ressalta-se que, enquanto para Posner (2007, p. 59) "uma regra suprime circunstâncias potencialmente relevantes à controvérsia [...] um padrão confere mais discricionariedade a quem examina os fatos". Nesse ponto, explica Posner:

\begin{abstract}
a regra gera tensão com as políticas sociais que a fundamentam, e que só podem ser imperfeitamente alcançadas quando a regra for aplicada sem se levar em conta as circunstâncias específicas da disputa. O padrão resolve aquele problema - o problema de chegar à justiça material, e não apenas à justiça tão somente formal -, mas, ao conferir uma ampla discricionariedade às autoridades que a aplicam, deixa o caminho aberto para os abusos. (grifo do autor). (Posner, 2007, p.60)
\end{abstract}

A incerteza, junto ao perigo dos abusos, se agrava quando regras são substituídas por padrões. Isso porque num regime de padrões, onde existem mais variáveis, torna-se mais difícil ainda prever o resultado de uma disputa jurídica. Os padrões exigem mais informações, em comparação às regras. Uma maior capacidade dos tribunais de lidarem com mais informações estaria ligada, de forma diretamente proporcional, ao crescimento dos padrões. Tendo em vista esta situação, e, sabendo-se que o raciocínio silogístico desempenha um papel menor na determinação de um resultado regido por um padrão, percebe-se aqui o declínio do formalismo jurídico. (POSNER, 2007)

Um perigo maior que o silogismo representa para a ideia de que pode determinar o direito, está no momento em que se transfere o enfoque da premissa menor (os fatos), para a premissa maior (a regra em si). Vale a adevertência:

a fonte do perigo não é, como se poderia pensar, o fato de que as regras têm exceções. Isso não é problemático em si mesmo, desde que as exceções sejam, elas próprias, regras, como é comum que o sejam. (Posner, 2007, p.61)

Entre os problemas com a governança por regras, destaca-se, num primeiro momento, que "a hipótese de incidência de uma regra pode ser incerta, e então os juízes terão de decidir continuamente se devem ou não aplicar a regra a situações previstas. Para Posner (2007, p.61) " Ocorre que, por exemplo, algumas vezes a regra não será capaz de apreender a realidade descrita, devendo os juízes, na ausência de conceito legislativo, "decidir o que a palavra deve significar para fins jurídicos, e não o que ela de fato significa." 
Nesse sentido, segundo o autor (2007, p.62) "as decisões que se exige que os juízes tomem para aplicar as regras aos fatos podem ser descritas quer como interpretação, quer como criação de exceções e ajustes ad hoc - na verdade, uma contínua reformulação das regras. "O autor (2007, p.63) ainda completa: "quanto mais antiga a regra, e quanto mais dinâmica a atividade regida por ela [...] mais os juízes serão pressionados a criar exceções e expansões ad hoc."

O segundo problema citado por Posner (2007, p. 62), referente à governança por regras, reside no fato de regras contraditórias poderem reger o mesmo ato. Neste ponto, critica: "regras contraditórias do ponto de vista lógico não podem ser aplicáveis à mesma atividade. O juiz tem o dever de eliminar a antinomia. A lógica, contudo, não Ihe diz qual regra deve ser descartada." Constata-se, também, que nem todos os casos serão abarcados pelo padrão lógico de regra e exceção, pois a aderência a uma regra não é uma imposição lógica, tendo em vista que ela não diz quando se deve segui-la. Com isso, conclui:

ficamos, assim, com o paradoxo de que uma questão jurídica pode ser ao mesmo tempo determinada e indeterminada: determinada porque uma regra clara dá-lhe tratamento, indeterminada porque o juiz não é obrigado a seguir a regra. [...] Além do mais, sustenta o ponto de vista de Holmes de que o direito é, na verdade, apenas uma previsão daquilo que os juízes farão com um determinado conjunto de fatos, uma vez que as regras não obrigam os juízes a fazer coisa alguma. (grifo do autor).(Posner, 2007, p.63)

Num último apontamento, Posner destaca que não serão intrinsecamente mais objetivas as decisões tomadas de acordo com uma regra do que seria aquela tomada por um padrão. Expõe que "as regras mascaram - não eliminam, e é possível que nem mesmo reduzam - o papel do subjetivo e do político na formação dos direitos e deveres jurídicos". Sugere que, ao se fazer uma comparação entre regras e padrões, vistos de um modo realista, percebe-se que as vantagens do primeiro sobre o último começam a cair. Nesse sentido, explica:

as vantagens principais são a redução da discricionariedade oficial - a discricionariedade das autoridades que administram as regras, mas não a daqueles que as criam - e a redução da incerteza relativa aos direitos e deveres jurídicos. Essas vantagens dependem, porém, do fato de se poder contar com um número não muito elevado de regras simples, relativamente imutáveis e claras em seu enunciado e sua aplicação - ideais que um sistema de regras jurídicas raramente alcança. (Posner, 2007, p.63) 
Considera que, mesmo havendo regras claras, estas poderiam existir em tão grande número que os indivíduos a elas submetidos não conseguiriam assimilá-las. Sugere ainda que, as razões que levam os juízes a se aterem às regras têm pouco, ou quase nada, a ver com a lógica, e freqüentemente não são, em absoluto, 'razões. $\mathrm{O}$ autor indica que

as diferenças de temperamento são, de fato, responsáveis por grande parte da evidente diferença entre os juízes no que diz respeito a interpretar as regras de maneira flexível, reconhecer livremente as exceções, transformar regras em padrões deliberadamente e, sem grandes constrangimentos, outorgar discricionariedade aos júris e aos juízes dos tribunais inferiores.(Posner, 2007, p.65)

Admite, no entanto, que há juízes mais tolerantes com a desordem, vendo o direito numa perspectiva de diálogo e questionamento, sendo sensíveis as particularidades de cada caso, contudo, sendo insuficientemente sensíveis aos custos da incerteza jurídica. (POSNER, 2007)

Voltando às regras jurídicas, Posner, ao examiná-las, realiza um comparativo entre essas e as regras de jogos e as da linguagem. No primeiro momento, identifica que as regas jurídicas são, em comparação àquelas dos jogos, igualmente habilitadoras ou repressivas. Ressalva, porém, que "o dever de jogar conforme as regras é mais imperativo nos jogos do que no direito, uma vez que neste elas podem ou não ser utilizadas". Assim esclarece:

\begin{abstract}
contudo, os juízes realmente têm uma licença limitada para "desobedecer" às regras ao modificá-las com o jogo já iniciado. Poderíamos eliminar o paradoxo ao afirmar que toda vez que os juízes infringem uma regra, fazemno com o objetivo de obedecer a uma regra de mais alto nível, ou que, se de algum modose permite que os juízes infrinjam as regras, isso mostra que o que eles fazem não é, na verdade, infringir regras. Isso, porém, seria um mero jogo de palavras e não alteraria o fato de que os juízes, com alguma freqüência (sic), decidem rejeitar ou modificar aquilo que, até então, parecera uma regra válida. (Posner, 2007, p. 67-68)
\end{abstract}

Outro ponto a ser visto é que, para os juízes, as regras podem ser vistas como guias, afim de que tenham orientação. Posner (2007, p.68) acredita que "o juiz que leva as regras exageradamente a sério pode ser apenas um burocrata que se prende a futilidades." Dessa forma, ilustra a ideia com o exemplo de que, um iniciante no esqui, mesmo tendo aprendido as regras concernentes à sua prática, permite-se que as infrinja, muitas vezes para evitar quedas. 
Em relação à linguagem, destaca que esta se assemelha ao direito no sentido de que suas regras também são mutáveis e se modificam no uso. Assim como, acrescenta, ambos se situam, de certo modo, além do certo e do errado. Exemplificando, mostra vocábulos que, mal compreendidos no passado, abarcaramse pelo costume e, hoje, não são mais passíveis de correção. Dessa forma, preconiza que, "tendo em vista que o direito, assim como a linguagem, valoriza a estabilidade, os erros jurídicos também podem ser sancionados pelo tempo e pelo uso. (POSNER, 2007)

As regras se relacionam de forma diferente com aqueles que as criam, do que com aqueles que não estão sujeitos a rever ou a revogá-las. Na perspectiva dos governantes, as regras podem ser facilmente manipuladas, pois estes possuem uma discricionariedade no mínimo ampla para revogar, rever ou interpretá-las. Conforme Posner (2007, p.71), "as sanções por não se aplicar uma regra não são as mesmas, e não costumam ser tão severas, quanto aquelas que se voltam contra os que não a obedecem."

É agradável pensar que os juízes se submetem às regras, ao invés de criálas. Contudo, eles se relacionam de forma diferente com essas, como visto no parágrafo acima, e mais: "podem, com certa moderação, mudar as regras, em especial aquelas do common law e do direito constitucional." Isso se dá, segundo Posner, pelo fato de que as regras não precisam ser cristalinas ou definidas para obrigar legalmente as pessoas a quem a elas devem submeter-se. Apesar disso, não se pode afirmar que as regras feitas pelos juízes não têm peso junto a eles mesmos. Posner ressalta:

[,..] mesmo as regras feitas por juízes têm peso junto aos mesmos, ou seja, que realmente existe uma política, ainda que flexível, de adesão ao precedente, com a dupla finalidade de estabilizar o direito e poupar o tempo dos juízes. (Posner, 2007, p.71)

Ao falar da estabilidade jurídica, se volta novamente para a questão da limitação da lógica no direito. Esclarece que, muitas leis, como as que regem a responsabilidade civil extracontratual, o direito concorrencial e 0 direito constitucional, passaram por grandes transformações no século XIX. Ainda assim, diz que (2007, p.72) "o processo pelo qual os juízes alteraram essas leis [...] não é um processo lógico, nem uma questão de corrigir erros de raciocínio silogístico 
cometidos por seus antecessores." Reconhece que, os juízes e advogados realmente usam a lógica, mas para isso recorrem a métodos mais simples. Isso não desmerece, todavia, o papel dela dentro do direito. Pelo contrário, mesmo Posner indica que a lógica terá um papel crítico a desempenhar, mesmo nos casos mais difíceis.

Para demonstrar esse papel crítico da lógica, cita o caso Bower vs. Hardwick. Diante do exposto, conclui:

\begin{abstract}
a lógica não irá decidir os casos mais difíceis. A lógica destruidora não é a lógica criadora. Demonstrar que uma opinião é ilógica não é o mesmo que demonstrar que o resultado é incorreto - uma observação particularmente pertinente quando, em um caso, tanto a opinião majoritária quanto a dissidente são ilógicas. (Posner, 2007, p. 74-75)
\end{abstract}

A partir de então, passa a investigar o campo da tributação federal, onde o litígio não constitui o cerne da prática, mas apresenta questões jusfilosóficas pertinentes a sua exposição. Explica ele que "a legislação e as regulamentações tributárias emanam com tamanha freqüência (sic) e quantidade [...] que a função judicial de suprir lacunas em textos legislativos e afins é raramente exercida." As brechas, contudo, sempre surgem, por mais detalhada ou precisa que seja a legislação. (POSNER, 2007)

Nesse sentido, Posner cita Joseph Isenbergh, que faz uma forte crítica à doutrina da "substância sobre a forma." Isenbergh defende uma abordagem formalista da interpretação em geral. Ao tempo em que desconstrói a doutrina citada, indica por que os juízes a adotam. Seria, nas palavras de Posner, porque "os juízes são às vezes preguiçosos, e estão freqüentemente (sic) desnorteados quando se veem às voltas com transações comerciais complexas." Ressalta ainda, que "Isenbergh não se limita a criticar o estilo intelectualmente indolente com que muitos juízes desempenham esse papel. Ele também critica o resultado, como no conhecido caso Gregory vs. Helvering." Afirma Isenbergh que a decisão tomada pela Suprema Corte é um erro. Em seu raciocínio, fundamentalmente formalista, "trata a lei tributária como se esta tivesse criado um mundo conceitual, como o conjunto de números reais ou os teoremas de Euclides, sem qualquer correspondência necessária com o mundo dos fatos." (Posner, 78-79) 
Afirma que a depreciação ora feita do formalismo jurídico pode parecer, aos críticos esquerdistas do liberalismo, um sinal evidente de uma crise deste. Entretanto, discorda dessa interpretação e acrescenta:

é desejável minimizar a discricionariedade das autoridades, inclusive a dos juízes, mas indesejável - e também impossível - eliminar totalmente a discricionariedade oficial. Parece evidente que os legisladores tenham, e devam ter, discricionariedade. (Posner, 2007, p.81)

O fato de os juízes usarem a discricionariedade para resolver casos difíceis não implica dizer que se tem um sistema "iliberal", pois "esferas de discricionariedade não são incompatíveis com o liberalismo." O autor ainda destaca que "o Estado Liberal foi sempre um misto de regra e discricionariedade, e a questão a ser colocada deveria ser se obtemos uma mistura melhor sob o liberalism o do que obteríamos nos tipos de regime preferidos por seus críticos. (POSNER, 2007)

Não é que ele se opõe a todo e qualquer formalismo. No entanto, expressa que "a questão prática é saber se tal sistema [jurídico] é melhor do que um sistema com mais regras ainda, e com menos discricionariedade, ou um sistema com mais discricionariedade e mais padrões ainda, mas com menos regras.

Outra parte interessante da obra, refere-se a discussão do espaço da discricionariedade na decisão judicial, e Posner o faz, especialmente a partir de algumas críticas que elenca da obra de Hart e de Dworkin, no tocante ao modo como tais autores vislumbram este espaço. $\mathrm{Na}$ verdade, o espaço para a discricionariedade judicial é também uma questão analisada como tendo que ser enfrentado pela problemática da filosofia do direito, pois reflete no modo como os juízes decidem, e, portanto, os fundamentos que o levam a decidir de uma ou outra forma.

Intitulado um defensor do pragmatismo, não poupa esforços na critica a autores como Dworkin e mesmo a Hart no que diz respeito ao espaço que tais autores concedem aos argumentos morais na decisão judicial. Segundo ele, para os positivistas de primeiro tipo, como Hart, uma das condições necessárias para que uma norma primária de obrigação seja uma norma jurídica é que essa norma seja identificada pela norma de reconhecimento do sistema - então, para Hart, todas as 
leis nazistas faziam parte do direito, mas o "direito" que foi aplicado pelo o Tribunal, não.

Posner defende o ponto de vista de Hart por ser mais exato, mas discorda dele quando este diz que os juízes saem do âmbito do direito; para o autor, isso depende do que se espera dos juízes, qual seja, para Hart na zona aberta em que as normas se esgotam, ao decidir o que fazer, o juiz é obrigado a fazer uma escolha, e, para esta, baseia-se na intuição e as experiências pessoais e não somente praticar 0 "raciocínio jurídico", o qual, segundo ele, Dworkin atribui uma natureza exagerada. Nas palavras do autor, em sua crítica a Dworkin, "o que ele deveria dizer é que os juízes não deixam de praticar o direito quando proferem decisões políticas, pois o direito e a política se interpretam. Sob o certo o direito é simplesmente a atividade dos juízes, e essa atividade frequentemente tem uma dimensão política". (POSNER, 2007)

Segundo Posner (2007, p.302), o direito não é algo que os juízes descobrem, mas sim o próprio nome da atividade: "é o conjunto de hipóteses que advogados e juízes de tribunais inferiores propõem a propósito de regularidade dos comportamentos dos juízes dos tribunais superiores". Nessa esteira, o autor não só acredita que os juízes decidem seus casos, como criam a teoria do Direito, significa dizer que o Direito é de certa forma o que os juízes fazem e o que eles também farão. Na verdade, para o autor, é "uma manobra do jogo político e ideológico" os juízes se voltarem para uma questão política ou moral, quando as regras do direito se esgotam, pois seu verdadeiro objetivo é ocultar a discricionariedade, vendendo uma imagem de decisão objetiva, o que ele denomina luta contra "moinhos de vento", pois se o provo é indiferente ao processo de argumentação jurídica que provoca a decisão, a esta, ele não é indiferente, logo, o público discute seu resultado.

A coincidência entre o direito e a moral seria que os dois são métodos para favorecer a cooperação que a sociedade precisa para progredir, e é essa coincidência que induz algumas pessoas a dizer que o direito respalda a moral, acrescentando sanções matérias às sanções morais. O autor defende que não seria útil descrever o direito como respaldo da moral, pois temos muitos princípios morais que não são ligados ao direito nem trazem sanção, como os exemplos que ele traz: mentir não é crime e este é um princípio moral, assim como fazer caridade também 
não é um dever legal, ao mesmo tempo temos condutas que são moralmente indiferentes e são abarcadas pelo direito e cominadas de sanção. Outro ponto que o autor destaca seria de, no caso de conflitos de princípios morais, os juízes não teriam que escolher um lado para moldar e seguir.(PONSER, 2007).

Para o autor, não teria um momento em que se delimitaria o esgotamento dos argumentos morais, e, portanto, poderiam os juízes sair à caça dos argumentos morais, políticos, jusnaturalistas; enfim, o fato é que indiferentemente de seus conteúdos, estando dentro de sua jurisdição, os juízes devem decidir seus casos, qualquer que seja sua fonte será legítima para a criação da decisão judicial:

\begin{abstract}
Os juízes se defrontam rotineiramente com questões que não podem ser resolvidas pela aplicação de um algoritmo, e que exigem, em vez disso, o emprego da razão prática - aquele conjunto de métodos, entre os quais as reações instintivas, que as pessoas usam para tomar decisões quando o uso dos métodos da ciência e da lógica não é possível ou produtivo. Isso não quer dizer que o juiz enfrenta um "dilema moral" [...] Assim também a atividade judicial: os juízes só defrontam dilemas morais quando o direito favorece um resultado que contradiz suas mais profundas crenças morais. [...] Mas aplicar um princípio moral a uma questão jurídica não é a mesma coisa que tomar partido em questões morais controversas e usar a filosofia moral normativa para resolver a disputa. Essa é a relação problemática entre a moral e o direito.(Posner, 2007, p.180).
\end{abstract}

Resumidamente, o direito para o autor é um processo inarticulado e sem rigor de decisão judicial, com múltiplas fontes, inclusive não positivadas pelo Direito, devendo o juiz fazer o que melhor puder, valendo-se de todas as informações que Ihe são trazidas, o que exige uma teoria do direito muito mais flexível a essa práxis, pois é uma atividade que somente pode ser compreendida de um contexto. Assim, não é a filosofia moral que terá resposta para as questões jurídicas, na verdade, entende que os dilemas morais é que tornam complexas essas questões difíceis. É então, o pragmatismo, que ajuda a buscar melhores resultados desimpedidos de dúvidas filosóficas ou morais, pois ele mesmo é compatível com essas duas concepções - na medida em que o determinante de uma decisão a priori deve ser os fins sociais avaliados no contexto decisório. (POSNER, 2007).

Outra abordagem interessante em sua obra, é exposta no capítulo intitulado "como decidir o direito constitucional legislado", em que expõe que casos como o United Steelworkers vs. Weber não podem ser decididos por algum método de interpretação neutro, pois estes exigem um clamor político ou ético. 
Dworkin, nesse sentido, para Posner, responde a esse clamor, argumentando que a ação afirmativa, objeto do caso citado, pode ser justificada a partir do conceito de igualdade. Segundo Posner (2007, p.,385) Dworkin tenta "transferir o plano de análise do modo de extrair o significado que, pode-se dizer, os legisladores introduziram na lei, para o modo de conferir o melhor significado ético ou político". Em sua visão, Dworkin introduz a seguinte problemática: "que direitos à igualdade têm os cidadãos enquanto indivíduos que poderiam invalidar programas voltados para importantes políticas econômicas e sociais, inclusive a política social de melhorar a igualdade em geral?" Dworkin, contudo, segundo Posner (2007, p.385), não tenta definir o termo igualdade, apenas pressupõe que a "política social de melhorar a igualdade em geral' tem a ver (e deve ter) com a igualdade dos resultados entre as raças".

Em Posner, temos que Dworkin concebe dois "direitos à igualdade" distintos. Um deles é o direito a igualdade de tratamento. Posner diz que "Dworkin acredita que só existam direitos à igualdade para coisas realmente importantes como votar, e não para oportunidades profissionais ou de emprego [...]"O segundo deles é o "direito a ser tratado como igual", que, conforme Posner (207, p.386), "[...] é apenas um direito de não ser tratado desumana ou arbitrariamente [...]”. Critica Dworkin, ao dizer que seu conceito de igualdade é "equivocado, rudimentar e surpreendentemente restrito".Da mesma forma, entende que a classificação de Dworkin, quando este "[...] tenta diferenciar a discriminação contra e a favor dos negros ao estabelecer uma distinção entre 'preferências pessoais' e 'preferências externas'[...]", pois acredita que preferências externas são, no fundo, preferências internas.

O autor sugere que, ao lidar-se com casos de direito legislado ou constitucional indeterminados do ponto de vista interpretativo, deve-se adotar um princípio de cunho abrangente, e assim faz menção à aplicação da teoria pedigree da legitimidade judicial. Ele (2007, p. 389) faz a seguinte proposta: "classificar todas as leis em duas categorias: aquelas que dizem aos tribunais para criar doutrina do common law (...) e aquelas que não têm tal delegação.

Desse modo, considera que a legislação deve ser declarada inaplicável, a não ser se esta aborde de maneira expressa a questão ou consigne-a ao common law. Contudo, saber qual parte está tentando obter vantagem da lei não será tarefa 
simples. Posner destaca que a proposta de Easterbrook (da teoria pedigree) é que "os tribunais não devem conferir às leis que não deleguem aos tribunais o poder de criar regras qualquer conseqüência (sic) fora daquelas situações factuais 'expressamente aludidas' pelo poder legislativo".

Assim, indica três maneiras de lidar com essa questão. A primeira trata de que "a situação factual deve ser incorporada pelos termos da lei do modo como estes eram entendidos quando da promulgação da lei". A segunda diz que "a situação deve ser incorporada pelos termos do modo como os entendemos hoje, a despeito do que os legisladores possam ter pretendido dizer através deles". A terceira possibilidade, que aparentemente Easterbrook tem em mente, revela que "as leis além das que delegam poderes de legislar e de criar políticas públicas aos tribunais devem ser objeto de uma interpretação restritiva". (Posner, 2007, p.389)

Posner responde que, o viés da terceira maneira deve-se muito pelo seu caráter político. Indica ele que Easterbrook "se refere às limitações ao processo legislativo incorporadas à Constituição (...) que se vêem (sic) frustradas se os juízes se permitirem interpretar o espírito (...) quanto a letra da lei. Explica Posner (2007, p.390) que "ao redigirem uma lei em termos gerais, os legisladores deram-lhe forçosamente uma ampla esfera de ação potencial, expandindo assim o alcance da opção judicial". Ainda completa:

\begin{abstract}
se um tribunal estiver razoavelmente seguro quanto ao que pretendiam os legisladores (ainda que freqüentemente (sic) não o esteja - no caso Weber, por exemplo), uma recusa em pôr em prática seus objetivos porque eles não puseram todos os pingos nos is só será defensável se se tiver alguma objeção baseada em princípios à legislação em geral. (Posner, p.390-391).
\end{abstract}

Portanto, para ele a questão não é saber se a teoria de Easterbrook é certa ou errada, pois ele, como outros, foi forçado a "defender uma teoria interpretativa em bases não-interpretativas". Defende em sua explanação que "a interpretação das leis é extremamente sensível às teorias do processo legislativo e, como se trata de teorias políticas controversas, não fornecem bases sólidas para as decisões judiciais”. Logo, para o autor (2007, p. 392) “a 'interpretação' não é fundamentadora; assenta-se instavelmente sobre bases políticas transitórias". 
Então faz menção a posição de CassSustein, que por sua vez acredita que as leis devem ser interpretadas a favor das minorias, tratando-se de casos complicados. Indica que Sustein, em seu estudo, faz a proposta de que os "juízes criem, ao modo common law, regras substantivas, padrões ou pressupostos para responder às questões que são colocadas pelas leis, mas às quais o legislativo não forneceu material adequado para respondê-las". (Posner, 2007, p. 392).

Para Sustein, citado por Posner, o common law "verdadeiro" se fundamenta em políticas públicas que "impõem um amplo consenso social, ainda que incompleto, como a justiça corretiva e a eficiência". O common law do direito legislado está impregnado por um conjunto de valores contestados e problemáticos, tal qual é a legislação. Assim, reflete:

essa politização do processo interpretativo é problemática - o que não significa negar que as abordagens alternativas sejam no fundo igualmente políticas, mas sim enfatizar a inevitabilidade da política na decisão dos casos complicados de direito legislado. (Posner, 2007, p. 393).

Sustein, segundo Posner, questiona se a melhor proposta seria ter uma orientação política abrangente, ou mesmo promover uma ordenação privada por meio da interpretação restritiva, ou, de outra forma, "adotar uma abordagem ad hoc, descentralizada" - destacando desde já que a vantagem da última está no fato de que os juízes tenderiam para um poder político difuso. Preconiza Posner:

quando os princípios da ação judicial são tão claramente políticos, os ganhos da decisão judicial ad hoc são questionáveis, e não temos a substância, mas apenas a sombra do formalismo e do Estado de Direito.(Posner, 2007, p.393)

Logo, o autor se questiona: então a comunicação nunca é possível? (grifos nosso). Para o autor, todas as interpretações de leis e da Constituição são decisões sobre políticas públicas tomadas por juízes. Do mesmo modo, critica os céticos que acreditam que a possibilidade de comunicação depende da epistemologia obsoleta que a torna "objetiva". Assim explica:

apesar de enfatizar devidamente a importância dos símbolos na comunicação, a teoria não é correta, ou é no mínimo radicalmente incompleta. Deixa de reconhecer que a maioria das comunicações se realiza sem imagens mentais; que os objetos físicos simples e facilmente visualizáveis constituem um tema pouco comum na comunicação - e que 
ainda assim a comunicação bem-sucedida depende de um conjunto de entendimentos tácitos [...]. (posner, 2007, p.394).

A comunicação escrita, também funciona, podendo-se provar isto com os mesmos indícios com que se prova que a comunicação oral funciona. Acredita que (2007, p. 394) "uma vez que descartemos a idéia (sic) de que a comunicação exige que se possa perscrutar a mente do emissor, não precisamos mais temer que o fato de que não existem mentes em grupo e, portanto, nenhuma 'intensão legislativa' em sentido literal impossibilita a comunicação de comandos através de leis".

Dessa maneira, acredita que é provável que "existam muitas interpretações de leis corretas". Estabelece que a comunidade que interpreta a Constituição e o significado das leis encontra-se fragmentada à medida que essas se tornam mais distantes com o passar dos anos. Conforme explica,

mesmo quando o legislativo revoga uma decisão judicial que interpreta uma lei, isso não mostra que a decisão estava errada; a composição do legislativo está condenada a mudar (e o equilíbrio das forças políticas pode ter mudado) entre a época em que a lei foi aprovada e aquela em que foi emendada para revogar a interpretação judicial. (Posner, 2007, p.397)

Ainda destaca que "o significado não reside simplesmente nas palavras de um texto, pois as palavras estão sempre apontando para alguma coisa que lhes é extrínseca".

a diversidade da cultura jurídica moderna torna inevitável a existência de uma vasta área de indeterminabilidade na interpretação, como parte do fenômeno mais amplo da indeterminabilidade jurídica (...) De novo, observamos o curioso fato de que a confiança epistêmica no direito depende fortemente do consenso político. (Posner, 2007, p.397-398).

Indica haver uma tensão existente dentro do formalismo ao mencionar o fenômeno da indeterminabilidade jurídica. Exemplifica então comparando um juiz que "acredita que os textos constitucionais e legais geralmente comunicam um significado determinado quando lidos criteriosamente", com aquele que "acredita que esses textos raramente comunicam um significado determinado". Destaca que o primeiro relutará a aderir o precedente no direito legislado e constitucional, enquanto o segundo tomará este por linha.

Fala então da hermenêutica, e de como os hermeneutas sugerem que é importante se por no lugar do autor que se está tentando interpretar, a fim de conseguir compreender o significado e os conflitos que ele estava tentando responder. Dessa forma, o documento deve ser lido como um todo. O problema da 
interpretação, como Posner o traz, é que não existem técnicas que proporcionem interpretações objetivas de textos difíceis. Apesar da hermenêutica mostrar o problema, ela por si não traz consigo também a solução.Isso, para Posner, significa dizer que saber se se deve interpretar os textos legais de forma ampla ou restritiva remete a um julgamento político, sensível ao temperamento dos juízes. (POSNER, 2007).

Apesar de defender a interpretação, reconhece que a presença do conceito, vago e impreciso, não é o melhor para a aplicação da lei e da Constituição. Para ele, a interpretação pode remeter a ideia de que há "um texto em cogitação, que o texto tem autoridade e que a decisão deve, de algum modo, remeter ao texto". Destaca ainda que, a justeza da intepretação depende de seu objetivo, e, no caso da interpretação das leis, não existe consenso sobre qual seria o objetivo da interpretação delas ou da Constituição. Seria fidelidade à intenção do constituinte originário? Certeza? Coerência?

Além do mais, para Posner, será mais difícil prever o resultado de casos de direito legislado e constitucional, quanto mais diversificado for o judiciário. Ainda assim, expõe ser contrário ao ponto de vista de Calabresi, que segundo o autor, considera que os tribunais deveriam poder revogar leis obsoletas. Ainda comenta:

O processo interpretativo é frequentemente indeterminado. $\mathrm{E}$ daí? $\mathrm{O}$ legislativo sempre pode rejeitar uma interpretação que não the agrade, e uma interpretação constitucional pode ser corrigida por uma emenda constitucional. (Posner, 2007, p. 405)

Contudo, mesmo Posner adverte que o processo de emenda constitucional é difícil e demorado, além de que as agendas do legislativo estão saturadas. Considera que os tribunais são, no final das contas, os principais criadores do direito legislado e constitucional.

O fato é que os problemas levantados na visão de Posner no tocante a filosofia do direito, nos permitem concluir algumas premissas acerca do pensamento do autor pragmatista, como, por exemplo, uma certa rejeição a idéia da autonomia do direito e de sua própria concepção enquanto ciência pura, bem como, uma severa crítica quanto a concepção da objetividade do direito. O que na verdade, busca impor um "alerta" a influência e os perigos da filosofia moral na definição das questões jurídicas, como também ao o perigo da crença do consensualismo sobre 
as regras e na crença na lógica jurídica como método seguro na solução dos problemas da vida no direito.

\section{REFERÊNCIAS}

POSNER, Richard A. Problemas de filosofia do direito. Trad. Jeferson Luiz Camargo. São Paulo: Martins Fontes, 2007. 